\title{
The Citrus Canker Epidemic in Florida: The Scientific Basis of Regulatory Eradication Policy for an Invasive Species
}

\author{
Tim R. Gottwald, Gareth Hughes, James H. Graham, Xiaoan Sun, and Tim Riley
}

\begin{abstract}
First and fifth authors: U.S. Department of Agriculture, Agricultural Research Service, Ft. Pierce, FL 34945; second author: University of Edinburgh, U.K.; third author: University of Florida, IFAS, Lake Alfred; and fourth author: Florida Department of Agriculture and Consumer Services, Division of Plant Industry, Gainesville. Accepted for publication 8 November 2000.
\end{abstract}

Increasing international travel and trade have rendered U.S. borders much more porous and dramatically increased the risk of introductions of invasive plant pests into agricultural crops (1). Nationally, the responsibility for safeguarding agriculture falls to the U.S. Department of Agriculture, Animal and Plant Health Inspection Service, Plant Protection and Quarantine (USDA, APHIS, PPQ). However, the current system for protecting agricultural industries has broken down allowing for an unprecedented number of introductions of exotic pests, including plant pathogens. Such introductions threaten crops and can hinder national and international agricultural markets and trade. In 1999, President Clinton announced an initiative for invasive species to address these issues and introduced an Executive Order on Invasive Species (10). The order is intended to coordinate and enhance federal government efforts to prevent introduction of invasive species and to provide for their control. The Executive Order calls for the appointment of a council, chaired by the Secretaries of Agriculture, Commerce, and the Interior, and composed of key federal agencies charged with developing an invasive species management plan. In response, the National Plant Board initiated a "stakeholder" review of the USDA, APHIS, PPQ safeguarding system in order to identify means to improve pest exclusion and detection of and response to invasive pest introductions (1).

Enter citrus canker. Currently in Florida, one such invasive species is Xanthomonas axonopodis pv. citri (Xac), a bacterial plant pathogen that causes Asiatic citrus canker. Citrus canker is an introduced plant disease that has received considerable press attention, has produced far-reaching political and socioeconomic impact in Florida, and has implications for national and international trade $(3,4)$. Although Xac is mostly a leaf and fruit-blemishing pathogen, the disease triggers immediate quarantines of areas with outbreaks in Florida, disrupting movement of fresh fruit $(3,11)$. The importance of citrus canker as a major invasive disease and the political forces that govern attempts to eradicate the disease were recently exemplified by the visit of the U.S. Secretary of Agriculture to the Homestead/Florida City area south of Miami on 22 March 2000 to view a major outbreak of the disease first hand. Secretary Glickman declared the South Florida canker outbreak area in Dade and Broward Counties a federal disaster area, opening the door for disaster relief funds and for U.S. Marshals to assist crews in expediting the cutting and removal of trees from homeowners' residences in metropolitan Miami (26). South Florida was one stop on a national tour conducted by the Secretary

Corresponding author: T. R. Gottwald; E-mail address: TGottwald@ushrl.ars.usda.gov

Publication no. P-2000-1120-010

This article is in the public domain and not copyrightable. It may be freely reprinted with customary crediting of the source. The American Phytopathological Society, 2001. of Agriculture to highlight non-native, invasive pests and diseases that threaten U.S. agriculture and natural resources (20).

Citrus canker has a long history. The disease was first found spread throughout the southeastern United States on imported seedlings from Japan in the early 1910s and was declared eradicated from Florida and the adjacent states in 1933. Citrus canker was discovered again in Manatee County Florida, south of Tampa Bay in the late 1980s, and was thought to be eradicated by 1994 . Two years thereafter, the disease re-emerged in the same area on the west coast of Florida where the 1980s outbreak had occurred. In the meantime, a new and separate infestation of citrus canker was discovered in urban Miami in 1995, that was estimated to have been introduced in 1992 or 1993 (17). Since that time the disease has spread from an initial area of 14 square miles near the Miami airport, to over 1,005 square miles in the metropolitan area plus an additional 260 square miles of urban and commercial citrus areas throughout the State. Genomic analysis of bacterial isolates from both time periods indicates that the latest Manatee County outbreak is a hold over from the 1980s outbreak that escaped the eradication program. However, the majority of current outbreaks of citrus canker are caused by the same genotype of Xac as in the Miami area. Thus, human-assisted movement of the bacterium from that source appears to have occurred several times. In early 2000, a third genomically distinct isolate of Asiatic citrus canker with an attenuated host range was identified in Palm Beach County on the east coast of Florida. Thus, there are presently at least three Xac genotypes that have been introduced into Florida in the recent two decades.

Although this bacterial disease is mostly a leaf and fruit-spotting malady, it results in immediate quarantines, disrupting national and international trade $(3,11)$. Although citrus canker can cause debilitation of trees and losses in fruit quality and yield, it is because of its socioeconomic and political impact that the disease is so devastating. If Xac should become endemic in Florida, it will effectively result in a prohibition of interstate commerce of fresh citrus fruit, which comprises approximately $20 \%$ of the State's $\$ 8$ billion commercial citrus industry (23). In addition, some cultivars of highly susceptible citrus species, such as grapefruit (Citrus paradisi), will have reduced economic viability due to the requirement for multiple bactericidal sprays per year to maintain yields and quality.

The Florida citrus industry is concentrated predominantly in the southern half of the State, in close proximity to rapidly expanding urban population centers. Because the outbreaks originated in urban areas, response to citrus canker, therefore, affects not just the citrus industry. Hundreds of thousands of urban homeowners have citrus trees as ornamentals and for dooryard fruit production and have had or will have their trees destroyed. The Florida Department of Agriculture and Consumer Services, Division of Plant Industry (DPI) and USDA, APHIS responded to the 1995 
discovery in Miami by forming a cooperative state/federal citrus canker eradication program (CCEP). Initially, the scientific basis for the eradication effort was provided by previous data from Argentina indicating that canker bacteria can spread up to $32 \mathrm{~m}$ (105 ft) during rainstorms associated with wind (30). This was translated into regulatory policy that resulted in the location of diseased citrus trees by survey teams, and mandated the removal and destruction of these trees and of "exposed trees", all those citrus trees within a $38-\mathrm{m}(125 \mathrm{ft})$ radius of a diseased tree; considering an additional $6 \mathrm{~m}(20 \mathrm{ft})$, presumably for the sake of caution (5). Trees are removed and destroyed because no effective chemical or horticultural methods of controlling the spread of canker are known. However, despite the use of the "125-ft rule" by the CCEP, the disease continued to increase in urban areas and the bacterium spread to numerous commercial citrus plantations in south Florida $(17,25)$.

The validity of the 125 - $\mathrm{ft}$ rule for containment of the pathogen spread came into question for three reasons: (i) spread of Xac in a central Florida grove in the early 1990s was as much as 2,600 ft in association with common rainstorms (16); (ii) catastrophic weather including hurricanes and tornadoes was documented by subsequent disease survey to cause spread of the bacterium up to 7 miles (17); and (iii) destruction of $125 \mathrm{ft}$ in citrus groves and urban areas failed to reduce the progress of disease in most locations. For these reasons the CCEP solicited a research study in collaboration with USDA-ARS and UF-IFAS to quantify the distance of dispersal of the canker pathogen in a subtropical setting in urban Miami. This 18-month epidemiological study involved a complete and repeated GPS-based census of over 19,000 healthy and diseased dooryard citrus trees in four study areas, three in Dade County and one in Broward County, with a combined study area of approxi- mately 10 square miles (18). During the study, there was a rapid increase in the incidence of diseased trees. For example, in one of the study areas, incidence increased from a single infected dooryard tree to 1,731 infected trees within a two square mile area (Fig. 1). The study was crucial for establishing that disease gradients resulting from bacterial dispersal occurred over distances far in excess of $125 \mathrm{ft}$ (Table 1).

Natural spread of citrus canker results from a combination of wind and rain. Rain wets canker lesions on citrus fruits, twigs, and foliage surfaces, allowing the bacteria that multiply in plant tissues to ooze to the surface. These bacteria are splashed by additional rain, picked up by wind currents, and blown some distance, and then splatter onto previously uninfected plant surfaces. Infection can be achieved through wounds or, if the winds have velocity $>8 \mathrm{~m} / \mathrm{s}$ (18 mph) (27,28), the inoculum can be forced directly through stomata and infect the mesophyll tissues beneath (19). Using National Weather Service data from the Miami International Airport weather station for rain and wind gusts, the epidemiological study established a close relationship between rainstorm events and subsequent increases in the incidence of canker-infected trees (17).

Impacts of the disease. One of the regulatory responses to citrus canker is the establishment of federal quarantine boundaries. Although the precise placement of such boundaries is a complex issue, they are usually located two or more miles beyond any known infestation (5). Within quarantine areas, movement of all citrus plant material is restricted. This affects both the citrus industry and homeowners with citrus trees. Commercial citrus nursery sales are prohibited. Commercial production must be handled in designated packinghouses where fruit is treated with disinfestants. Some processing plants and packinghouses refuse to accept fruit from quarantine areas. Market distribution of fresh fruit

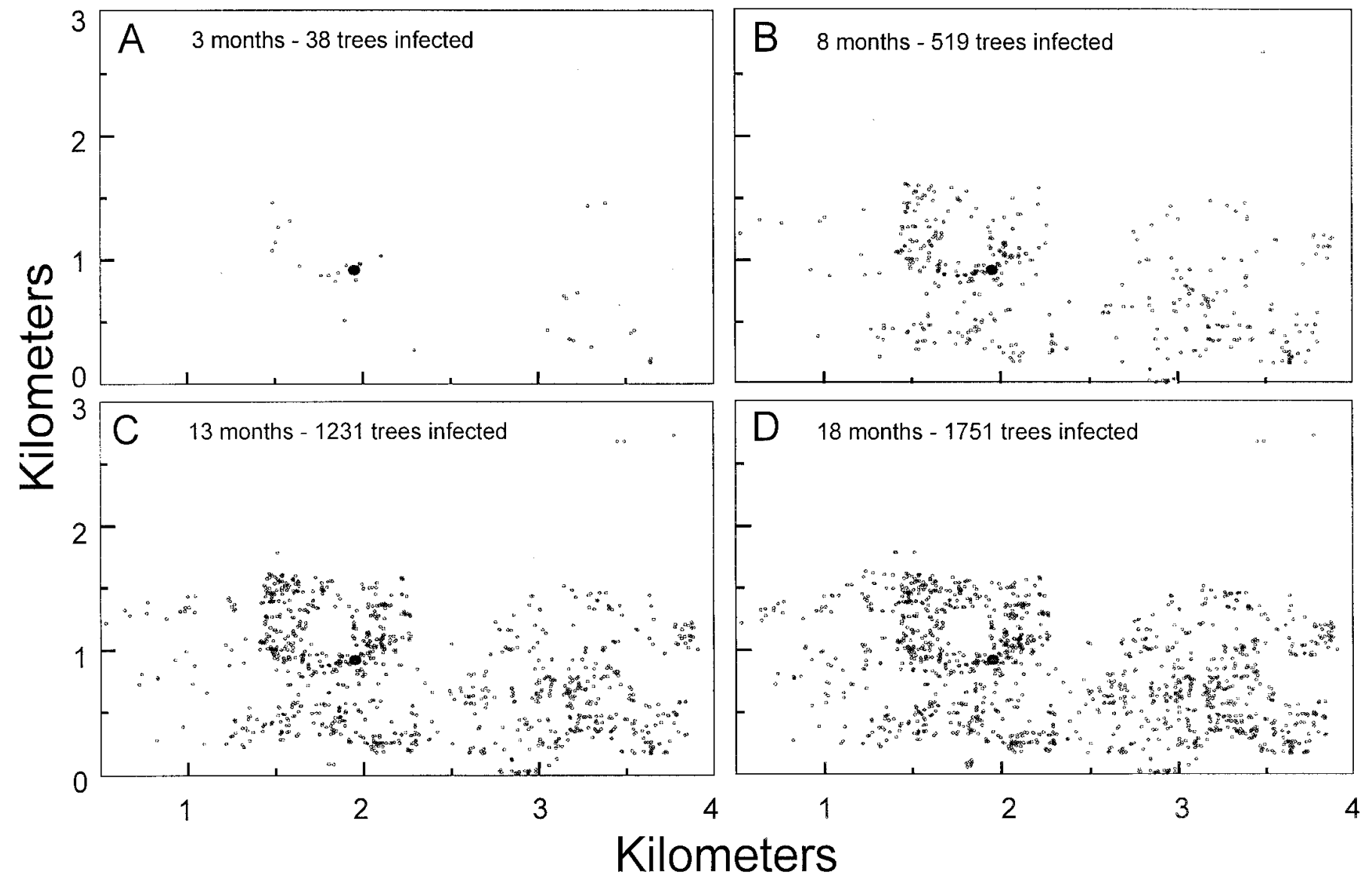

Fig. 1. Spatial arrangement of citrus canker-infected trees during four time periods in study site 1 in Miami, Dade County. Spatial location was determined by differential global positioning system (GPS). The initial focal tree, determined by age of infection, is depicted by a large black dot. Subsequent infected trees depicted by smaller dots. 
from regulated areas is often restricted. Harvesting and transport equipment is required to undergo disinfestation. Commercial citrus plantings are required to have decontamination stations at farm gates, a precaution that has recently become a State-wide requirement even outside of regulated areas. Replanting of citrus, in both commercial groves and residential areas that have undergone eradication efforts, is illegal until canker has been declared eradicated and the area has been free of the disease for 2 years. In residential areas, people are informed that transporting fruit to neighbors and family is illegal. Even lawn and garden services are required to decontaminate any equipment moved between properties. Intensive media coverage and public relations expertise are employed to publicize these measures.

Impacts of epidemiological research. In December 1998, the Miami epidemiology study was reviewed by a group of scientists and regulatory officials. The consensus was (i) that the $125-\mathrm{ft}(38 \mathrm{~m})$ radius used to define exposure was inadequate to suppress the continued spread of canker, and (ii) that although disease spread was detected up to $58,850 \mathrm{ft}(17,942 \mathrm{~m})$, the majority of new canker infections occurred within approximately 1,900 ft (579 m) of known source trees. As a result, a new regulation, the "1,900-ft rule" was put into practice in late 1999, requiring the removal and destruction of diseased citrus trees and of all citrus trees within a $1,900-\mathrm{ft}$ radius of a diseased tree $(13,21)$. The $1,900-\mathrm{ft}$ rule has been challenged in court and upheld and is considered in the Florida citrus canker action plan (5). Each circle of 1,900-ft radius represents 0.41 square miles $\left(1.06 \mathrm{~km}^{2}\right)$ (Fig. 2). The implementation of the 1,900-ft rule will result in an effective clear-cutting of the majority of dooryard citrus within approximately 793 square miles $\left(2,054 \mathrm{~km}^{2}\right)$ of the Miami metropolitan area in Dade and Broward Counties. An estimated 750 thousand dooryard trees will be removed from urban areas in Dade and Broward Counties within the next year (6) (Fig. 3). The reaction of residents whose trees have been or will be removed ranges from general acceptance to strong resistance. Occasionally personal threats to eradication program personnel and administrators and lawsuits have been brought against the state by residents and municipalities $(9,22)$. Commercial citrus has also been affected by the requirement for removal of large numbers of productive trees in several areas of the State. One of the worst hit areas is the lime industry south of Miami where approximately $40 \%$ of the 3,676-acre $(1,488 \mathrm{ha})$ industry has been destroyed in an attempt to curb further spread of citrus canker there (15).

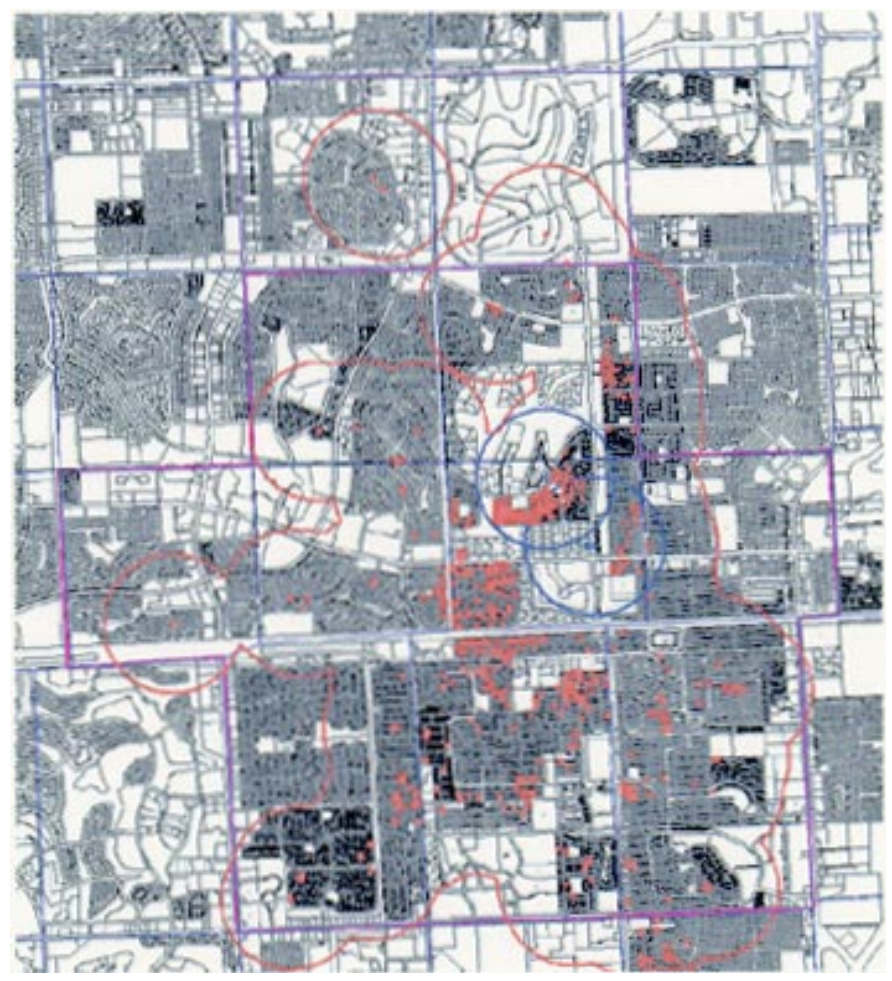

Fig. 2. Map of a portion of residential Broward County, Florida. Blue dots depict examples of two individual citrus canker-infected trees located in two residential properties. Blue circles surrounding the blue dots indicate areas within 1,900-ft radii of these two infected trees. Red dots indicated all known citrus canker-infected trees within the mapped area. Red lines depict the boundary defined by overlapping circles of $1,900-\mathrm{ft}$ radii that define the potential area exposed to citrus canker, within which all citrus canker-infected and noninfected trees will be removed in an attempt to eradicate the disease.

TABLE 1. Results of the epidemiology study of citrus canker dispersal ${ }^{\mathrm{a}}$

\begin{tabular}{|c|c|c|c|c|c|c|c|c|}
\hline \multirow[b]{2}{*}{ Area } & \multirow[b]{2}{*}{ Assessment period (30 days) } & \multicolumn{2}{|c|}{ Trees } & \multicolumn{3}{|c|}{ Distance (ft) necessary to capture } & \multirow[b]{2}{*}{$\%$ Captured at $125 \mathrm{ft}$} & \multirow[b]{2}{*}{$\%$ Captured at $1,900 \mathrm{f}$} \\
\hline & & Focal & Newly infected & $90 \%$ & $95 \%$ & $99 \%$ & & \\
\hline \multirow[t]{6}{*}{1} & Apr/May 1998 & 38 & 14 & 800 & 4,150 & 4,150 & 13 & 93 \\
\hline & May/Jun 1998 & 52 & 38 & 1,450 & 1,450 & 1,650 & 44 & 100 \\
\hline & Jun/Jul 1998 & 90 & 72 & 1,200 & 1,600 & 1,900 & 44 & 100 \\
\hline & Jul/Aug 1998 & 162 & 234 & 700 & 800 & 1,450 & 36 & 100 \\
\hline & Aug/Sep 1998 & 396 & 123 & 350 & 500 & 700 & 44 & 100 \\
\hline & Sep/Oct 1998 & 519 & 31 & 250 & 950 & 950 & 72 & 100 \\
\hline \multirow[t]{6}{*}{2} & Nov/Dec 1997 & 4 & 17 & 2,050 & 3,400 & 3,400 & 18 & 88 \\
\hline & Dec 1997/Jan 1998 & 21 & 7 & 950 & 950 & 950 & 14 & 100 \\
\hline & Jan/Feb 1998 & 28 & 2 & 450 & 450 & 450 & 50 & 100 \\
\hline & Feb/Mar 1998 & 30 & 21 & 450 & 500 & 700 & 44 & 100 \\
\hline & Mar/Apr 1998 & 51 & 31 & 450 & 1,050 & 2,050 & 52 & 97 \\
\hline & Apr/May 1998 & 82 & 48 & 400 & 450 & 550 & 75 & 100 \\
\hline \multirow[t]{4}{*}{3} & Mar/Apr 1998 & 5 & 2 & 200 & 200 & 200 & 50 & 100 \\
\hline & Oct/Nov 1998 & 9 & 6 & 1,950 & 1,950 & 1,950 & 33 & 83 \\
\hline & Feb/Mar 1999 & 16 & 10 & 900 & 900 & 900 & 10 & 100 \\
\hline & Mar/Apr 1999 & 26 & 5 & 850 & 850 & 850 & 20 & 100 \\
\hline \multirow[t]{6}{*}{4} & Nov/Dec 1997 & 3 & 41 & 11,140 & 19,450 & 19,700 & 7 & 12 \\
\hline & Dec 1997/Jan 1998 & 44 & 49 & 1,100 & 10,750 & 20,800 & 44 & 92 \\
\hline & Jan/Feb 1998 & 93 & 14 & 1,350 & 2,700 & 2,700 & 13 & 93 \\
\hline & Feb/Mar 1998 & 107 & 14 & 2,950 & 58,850 & 58,850 & 40 & 67 \\
\hline & Mar/Apr 1998 & 121 & 108 & 900 & 1,400 & 3,150 & 53 & 98 \\
\hline & Apr/May 1998 & 229 & 62 & 700 & 2,050 & 2,350 & 63 & 94 \\
\hline
\end{tabular}

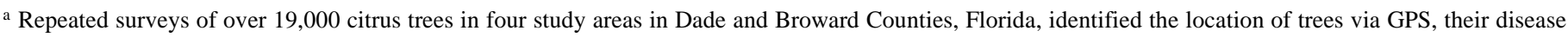
status and, for infected trees, age of the oldest lesion. In each successive time period, the distances from all trees newly infected to the nearest identified previously infected (focal) tree were calculated. The results thus provide conservative estimates of dispersal distances for the citrus canker pathogen. All measurements are shown in feet rather than meters because this is the unit of measure used by the eradication program in Florida. Time periods are 30 days in duration but are not necessarily consecutive. Instead they represent periods when new disease increase was sufficient to allow dispersal measurements.
} 
Removal of diseased and exposed trees is one part of the eradication program. Detection of new infections is another. Citrus canker has continued to spread northward along the east coast of Florida toward the Indian River citrus production area of St. Lucie and Martin Counties, which consists mainly of highly susceptible plantings of grapefruit. A second important outcome of the canker

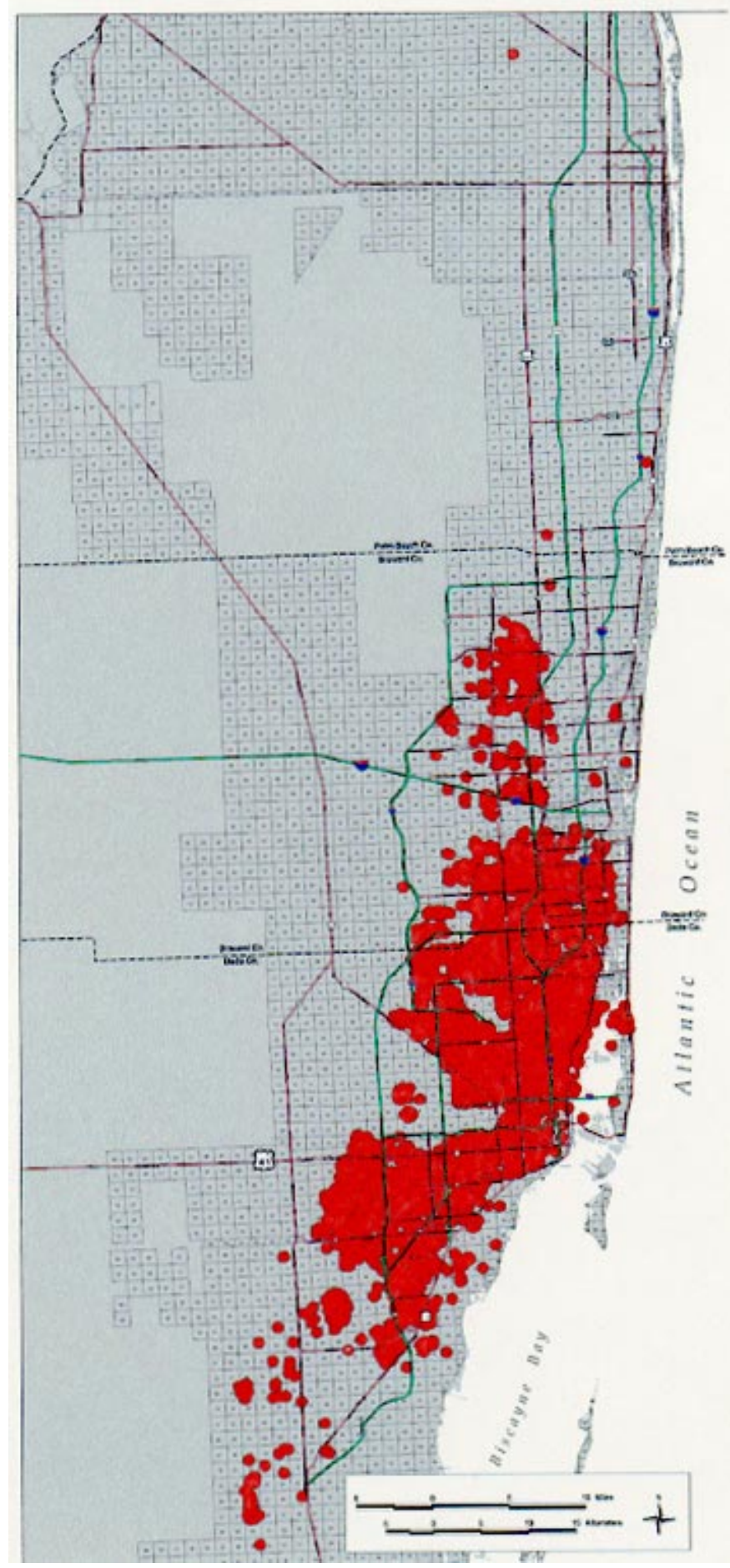

Fig. 3. Projected outcome of the implementation of the 1,900-ft regulation/ law for eradication of citrus canker in metropolitan Miami, Dade and Broward Counties of Florida. Each square depicts a one square mile section. Red circles depict areas of 1,900-ft radius surrounding a citrus canker-diseased tree, within which citrus trees are defined as 'exposed', on the basis of measurements of disease dispersal gradients from an epidemiological study in the urban Miami area. Note that the overlapping of such circles means that implementation will result in an effective clear-cutting of citrus in large portions of this metropolitan area. epidemiology study is the adoption of sentinel tree survey method. Arrays of approximately 144 existing dooryard trees of susceptible cultivars in a 12 by 12 arrangement (trees approximately $440-\mathrm{ft}$ apart) covering each square mile are used as an early warning system for new canker outbreaks (Fig. 4). Beginning in June 2000, a 15 -mile $(25 \mathrm{~km})$ wide by 20 -mile $(33 \mathrm{~km})$ long sentinel-tree area in Palm Beach County, north of the Miami outbreak area, was visually surveyed on a repeated 30-day rotation. As a result, three new outbreaks of canker have been detected to date. Detection of these new outbreaks of canker results in removal and destruction of diseased and exposed trees under the 1,900-ft rule. The success of the sentinel tree grid system has prompted its expanded use further north along the eastern coast of Florida into Martin and St. Lucie Counties, and there are now plans to implement it elsewhere in the State.

Reaction. The timely implementation of the 1,900-ft rule and the sentinel tree grid system would not have been feasible in 1999, given existing CCEP funding and manpower constraints. However, once the results of the epidemiological study became widely known and understood, citrus industry organization groups pressured the CCEP for a more effective eradication effort. These groups also immediately lobbied state and federal sources for financial support for stepped up implementation of the 1,900-ft rule. Within a matter of days the Governor and Commissioner of Agriculture of Florida and USDA, APHIS announced that \$175 million of combined state and federal funding would be directed at an allout effort to eradicate citrus canker from the Miami outbreak area within 1 year $(7,11,13,21)$. In addition, $\$ 40$ million is to be allocated for indemnification of affected urban residents and some commercial citrus producers $(17,24)$.

An unfortunate consequence of the $1,900-\mathrm{ft}$ rule is that its unpopularity with both commercial citrus concerns and residential citrus owners who are adversely affected by it places the scientists involved in the study at odds with groups whom they are attempting to help. Compensation for affected residents is available through the "Florida Shade" program that provides a \$100 voucher, redeemable at local retail garden centers, for each property from

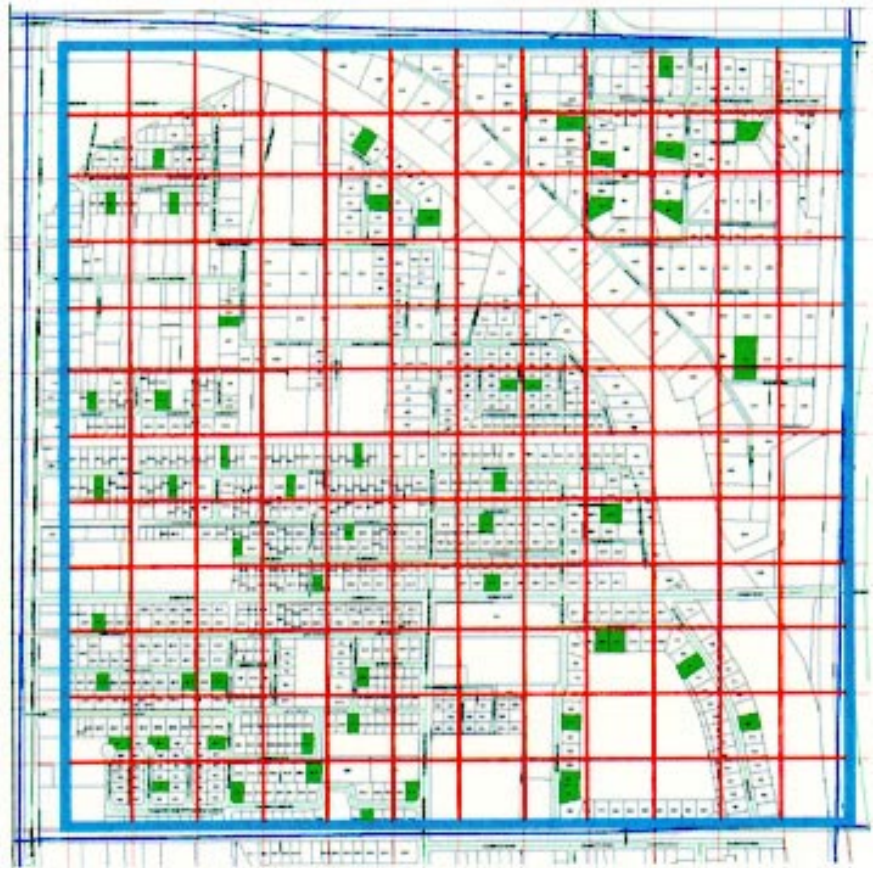

Fig. 4. Example of the practical implementation of the sentinel tree grid system. The grid depicted by the red lines divides the one square mile into 144 subsections. Where possible, within each subsection a legal property is selected on which one or more citrus trees highly susceptible to citrus canker are located (depicted in green). The result is an irregular array of trees that can be resurveyed for new canker infections on a 30-day rotation. 
which citrus trees have been removed and destroyed (12). This has helped to placate some, but certainly not all, of the residential owners of citrus. For commercial citrus producers, canker-related losses prior to November 1998 can be indemnified on an acreage basis. After that time, indemnification is restricted because federal crop insurance was amended to include coverage for citrus cankerrelated losses. However, for both urban residents and commercial growers, indemnification cannot fully offset the implications, whether esthetic or commercial, resulting in severe political and economic penalties for Florida's citrus industry.

The future. Complete eradication of an invasive species that has spread to the extent that citrus canker has in Florida is extremely difficult. Some researchers, growers, and residents dispute the concept and feasibility of eradication, and the question thus arises, "Can we live with citrus canker?" Several counties in southeast Asia and elsewhere have lived with canker for decades, but production costs increase, some cultivars are too susceptible and are no longer commercially feasible to grow, and national and international markets are lost due to quarantines and embargos (23). The obvious implication is that failure to attempt eradication will result in severe political and economic penalties for Florida's citrus industry. Unfortunately, even if eradication is achieved, there is a high probability for reintroduction of Xac in the future. Surveillance programs such as the sentinel tree grid system will need to be maintained in order to realize the benefits of eradication for the future. Furthermore, approximately $\$ 8$ million of the $\$ 175$-million eradication budget is projected to be used to fund new research on citrus canker dedicated to detection, eradication, control strategies, and development of host resistance.

The magnitude of response to the current citrus canker epidemic in Florida is unprecedented in plant pathology and represents a scale of public attention and governmental efforts that would normally be devoted to eradication of a newly introduced human or livestock pathogen. Even so, the attendant costs of eradication and compensation for canker losses may be equaled or surpassed by the current attempts to survey and control other invasive pests, such as Plum pox virus of stone fruits in eastern North America and the spread of Pierce's disease bacterium, Xylella fastidiosa, by the glassy winged leafhopper in California, for example. Survey and eradication strategies for these newly discovered outbreaks are as heavily reliant on results of epidemiological studies of the vector and pathogen spread as has been the case for citrus canker eradication. The escalation of international travel and commerce has opened a new era, during which we will likely have to battle invasive species introductions in unprecedented numbers and eradication and containment efforts of previously unparalleled magnitude. As such, citrus canker currently stands as a major test case for USDA, APHIS, PPQ safeguarding policies and procedures designed to improve protection for U.S. agriculture against introductions of invasive pest species now and in the future (1). A daunting concern is the probability in the near future of simultaneous multiple introductions of invasive agricultural pest species. The question arises, can we afford to allocate sufficient combined state/federal resources to be directed toward simultaneous battles fronts? In a society that is moving rapidly toward high-tech business and away from agrarian ideals, can agricultural commodity groups and regulatory agencies demonstrate sufficient socioeconomic need and awareness to the public and political funding sources to fund such efforts to protect U.S. agriculture? Perhaps the more sobering question is, can we afford not to?

\section{ACKNOWLEDGMENTS}

We thank the many disease surveyors and officials in the Citrus Canker Eradication Program, the Florida Department of Agriculture and Consumer Services, Division of Plant Industry, the U.S. Department of Agriculture, Animal and Plant Health Inspection Service who contributed to the Miami epidemiology study, and J. Saddler for supplying the graphic depicting the results of deploying the new eradication protocol.

\section{LITERATURE CITED}

1. Anonymous. 1999. Safeguarding American Plant Resources-A stakeholder review of APHIS-PPQ safeguarding system-Summary of issues and recommendations. http://www.aphis.usda.gov/ppq/safeguarding.

2. Anonymous. 2000. The Plant Protection Act. Introduced by the 106th Congress as H.R.1504 and S.910.

3. Anonymous. 1997. Importation of fresh citrus fruit (Sweet orange, Citrus sinensis, lemon, C. lemon, and grapefruit, C. paradisi) from Argentina into the continental U.S. http://www.aphis.usda.gov/oa/citrus.

4. Anonymous. 1997. Xanthomonas axonopodis pv. citri. Pages 1101-1108 in: Quarantine Pests for Europe. CAB International, Wallingford, U.K.

5. Anonymous. 1989. Florida citrus canker action plan. Fla. Dep. Agric. Consum. Serv., Gainesville.

6. Anonymous. 2000. Minutes of the April 1, 2000, Florida Citrus Canker Technical Advisory Task Force. Fla. Dep. Agric. Consum. Serv., Gainesville.

7. Anonymous. 2000. Minutes of the March 17, 2000, Florida Citrus Canker Technical Advisory Task Force. Fla. Dep. Agric. Consum. Serv., Gainesville.

8. Anonymous. 2000. Agriculture and horticulture protection. State of Florida Legislature, Senate Bill 1114er.

9. Brecher, E. J. 2000. 'Casualties' upset residents. Miami Herald, June 16.

10. Clinton, W. J. 1999. Presidential Executive Order 13112 on invasive species (EOIS), 6183 Federal Register 24:25, February 8 .

11. Compton, L. 2000. Citrus canker quarantine areas to be expanded. Fla. Dep. Agric. Press Release No. 4-3-2000.

12. Compton, L. 2000. Crawford announces receipt of Shade Florida funds and agreement with retailer. Fla. Dep. Agric. Press Release No. 4-28-2000.

13. Compton, L., and Fagan, M. 2000. Stepped-up canker eradication effort is launched. Fla. Dep. Agric. Press Release No. 2-23-2000.

14. Cope, Shevin, and Sorondo. 2000. Sapp Farms Inc. versus Florida Department of Agriculture and Consumer Services. Third District Court of Appeals, State of Florida, Case 3D00-487.

15. Gorman, S. 2000. Bill may help lime farmers. Miami Herald, April 1.

16. Gottwald, T. R., Graham, J. H., and Egel, D. S. 1992. Analysis of foci of infection of Asiatic citrus canker in a Florida citrus orchard. Plant Dis. 76:389-396.

17. Gottwald, T. R., Graham, J. H., and Schubert, T. S. 1997. An epidemiological analysis of the spread of citrus canker in urban Miami, Florida, and synergistic interaction with the Asian leafminer. Fruits 52:383-390.

18. Gottwald, T. R., Sun, X., Riley, T., and Graham, J. 1999. Estimating spread of citrus canker in urban Miami via GPS. (Abstr.) Phytopathology 89(suppl.):S29.

19. Graham, J. H., Gottwald, T. R., Riley, T. D., and Achor, D. 1992. Penetration through leaf stomata and growth of strains of Xanthomonas campestris in citrus cultivars varying in susceptibility to bacterial diseases. Phytopathology 82:1319-1325.

20. McAvoy, S. 2000. Secretary of Agriculture's national tour to highlight non-native, invasive pests and diseases that threaten American agriculture and natural resources. Release No. 0085.00. http://www.usda.gov/ news/releases/2000/03/0085.

21. McElroy, T. 2000. Crawford unveils bold new canker plan. Fla. Dep. Agric. Press Release 02-11-2000.

22. Merzer, M. 2000. Double whammy socks farmers in South Florida. Miami Herald, February 27.

23. Muraro, R. P. 1986. Observations of Argentina's citrus industry and citrus canker control programs with estimations of additional costs to Florida citrus growers under a citrus canker control program. Food Res. Econ. Dep. Univ. Fla., Gainesville Staff Paper 289.

24. Radelat, A. 2000. Growers to get aid on canker: House, Senate OK $\$ 13$ million. Miami Herald, May 26.

25. Samuels, A., and Bolstad, E. 2000. Citrus canker claims thousands of Broward trees. Miami Herald, July 29.

26. Schultheis, M. B. 2000. Glickman makes disaster declaration for four Florida counties. U.S. Dep. Agric. Press Release No. 0093.00. http:// www.usda.gov/news/releases/2000/03/0093.

27. Serizawa, S., and Inoue, K. 1975. Studies on citrus canker, vol. 3. The influence of wind blowing on infection. Bull. Schizuoka Pref. Citrus Exp. Sta. 11:54-67.

28. Serizawa, S., Inoue, K., and Goto, M. 1969. Studies on citrus canker, vol. 1. Dispersal of the citrus canker organism. Bull. Schizuoka Pref. Citrus Exp. Sta. 8:81-85.

29. Stall, R. E., and Civerolo, E. L. 1991. Research relating to the recent outbreak of citrus canker in Florida. Annu. Rev. Phytopathol. 29:399420.

30. Stall, R. E., Miller, J. R., Marco, G. M., and de Echenique, B. I. C. 1980. Population dynamics of Xanthomonas citri causing cancrosis of citrus in Argentina. Proc. Fla. State Hortic. Soc. 93:10-14. 